\title{
Note
}

\section{First evidence of White-footed Deer Mouse (Peromyscus leucopus) on mainland New Brunswick, Canada}

\author{
Howard M. Huynh ${ }^{1,2,3, *}$, Donald F. McAlpine ${ }^{2}$, and Scott A. Pavey ${ }^{1}$ \\ ${ }^{1}$ Canadian Rivers Institute Genomics Laboratory, University of New Brunswick, Saint John, New Brunswick E2L 4L5 Canada \\ ${ }^{2}$ Department of Natural History, New Brunswick Museum, 277 Douglas Avenue, Saint John, New Brunswick E2K 1E5 Canada \\ ${ }^{3}$ Natural History Campus, Canadian Museum of Nature, Gatineau, Quebec J9J 3N7 Canada \\ *Corresponding author: hmhuynh11@gmail.com
}

Huynh, H.M., D.F. McAlpine, and S.A. Pavey. 2021. First evidence of White-footed Deer Mouse (Peromyscus leucopus) on mainland New Brunswick, Canada. Canadian Field-Naturalist 135(3): 245-249. https://doi.org/10.22621/cfn.v135 i3.2625

\begin{abstract}
White-footed Deer Mouse (Peromyscus leucopus) and the closely related, and more northerly ranging, Deer Mouse (Peromyscus maniculatus) broadly overlap in distribution and are often difficult to distinguish from each other. Based on molecular genetic data (cytochrome $b$ gene), we report two new distribution records for P. leucopus for New Brunswick, Canada, the first mainland localities for this species in the province. Previous sampling of Peromyscus in New Brunswick may have overlooked the presence of $P$. leucopus, possibly because the specimens collected were all assumed to be $P$. maniculatus. However, current detection in New Brunswick may be part of a broader recent northward range expansion documented to be underway in P. leucopus. Although our use of a single mitochondrial gene to identify P. leucopus does not eliminate the possibility that the New Brunswick specimens are of hybrid origin, our results support the presence of $P$. leucopus in New Brunswick and suggest more detailed analyses will be required to determine the nature of any genetic interaction between P. leucopus and P. maniculatus in the province. Recognition of morphologically cryptic Peromyscus in southern New Brunswick also emphasizes the need to incorporate comprehensive methods to ensure the correct identification of specimens of this genus in Maritime Canada. We also note the potential implications of this discovery with respect to the incidence of Lyme disease in New Brunswick.
\end{abstract}

Key words: Distributional range; Peromyscus; White-footed Mouse; New Brunswick distribution; Lyme disease

White-footed Deer Mouse (Peromyscus leucopus) is one of several species of Nearctic rodents in the speciose genus Peromyscus. The species tolerates variable environmental conditions, but is most abundant in warm, wooded-shrubby habitats (Kaufman et al. 1983). Compared with the closely related Deer Mouse (Peromyscus maniculatus), P. leucopus has a less northward-ranging distribution in eastern Canada; the extent of the species' northern range is believed to occur across southern Ontario and Quebec, with a disjunct Maritime population confined to Nova Scotia (Hall 1981; Forbes et al. 2010).

Recent studies have documented P. leucopus in new localities in northeastern North America, which suggests the species is undergoing a northward range expansion, perhaps in response to climate warming (Roy-Dufresne et al. 2013; Fiset et al. 2015; Garcia-Elfring et al. 2017). Huynh et al. (2021) recently documented the presence of P. leucopus on Grand Manan Island, based on specimens taken in 2011 and identified via molecular genetic methods. Those vouchers represented the first New Brunswick reports and emphasized the need to establish whether the species was present on the adjacent mainland. Here we report the first evidence for $P$. leucopus on mainland New Brunswick, likewise supported by molecular genetic data, and discuss wildlife management implications of this information.

In 2013-2014, Peromyscus spp. were collected from various localities throughout New Brunswick using museum special snap traps (Woodstream Corporation, Lititz, Pennsylvania, purchased from Forestry Suppliers, Inc., Jackson, Mississippi, USA) and Sherman live traps (BioQuip Products, Inc., Rancho Dominguez, California, USA). Mice were collected from several trap lines of 100-125 traps deployed 
at $\sim 5-\mathrm{m}$ intervals in microhabitats (e.g., entrance to burrows, runways) that appeared suitable for Peromyscus. All specimens $(n=92)$ were prepared as traditional museum vouchers (skin and skull), with tissues extracted and preserved in 95\% ethanol and archived in the New Brunswick Museum frozen tissue collection.

Genomic DNA was extracted from subsamples of frozen tissues at the Canadian Rivers Institute Genomics Laboratory using an OMEGA DNA extraction kit (Omega Bio-tek, Inc., Norcross, Georgia, USA). DNA samples were subsequently stored in elution buffer (Tris) and archived at $-80^{\circ} \mathrm{C}$. The entire cytochrome $b$ gene (1143 base pairs) for almost all specimens was amplified via polymerase chain reaction (PCR) using primers MVZ05 (Smith and Patton 1993) and PERO3' (Tiemann-Boege et al. 2000). The PCR thermal profile consisted of the following: initial denaturation at $95^{\circ} \mathrm{C}$ for $2 \mathrm{~min}$, followed by 35 cycles of denaturation at $95^{\circ} \mathrm{C}$ for $1 \mathrm{~min}$, annealing at $51^{\circ} \mathrm{C}$ for $1 \mathrm{~min}$, and extension at $72^{\circ} \mathrm{C}$ for $2 \mathrm{~min}$, with a final extension at $72^{\circ} \mathrm{C}$ for $7 \mathrm{~min}$. PCR products were subjected to electrophoresis on a $1 \%$ agarose gel and then viewed on a molecular imager(ChemiDoc XRS+ Gel Imaging System, Bio-Rad Laboratories, Montréal, Quebec, Canada) to confirm successful amplification of the target gene.

The PCR products were then shipped to Genome Quebec for Sanger sequencing. Resulting sequences were aligned (using ClustalW, a standard general purpose software program for aligning nucleotide sequences) and proofed using the program MEGAX (Kumar et al. 2018); chromatograms were examined to verify all base changes. Sequences were then input into BLAST (Basic Local Alignment Search Tool, developed by the National Center for Biotechnology Information) to ascertain species identity (i.e., P. maniculatus or P. leucopus) and to compare with other Peromyscus sequences. Among the 85 samples sequenced (seven of the original 92 did not produce suitable PCR product), two specimens were identified as P. leucopus: an adult, lactating, female, $172 \mathrm{~mm}$ in total length, trapped 28 May 2014 at Blacks Harbour, Charlotte County $\left(45.059^{\circ} \mathrm{N}, 66.785^{\circ} \mathrm{W}\right.$; NBMMA-13000) and an adult male with testes $9 \mathrm{~mm}$ and total length $159 \mathrm{~mm}$, trapped 6 August 2014 at Lake Utopia, Charlotte County $\left(45.170^{\circ} \mathrm{N}, 66.794^{\circ} \mathrm{W}\right.$; NBM-MA-14183; Figure 1). NBM-MA-13000 was collected concurrently with $P$. maniculatus, Redbacked Vole (Myodes gapperi), and Masked Shrew (Sorex cinereus), while NBM-MA-14183 was the sole specimen collected at the Lake Utopia site. The remaining 83 specimens were determined to be $P$. maniculatus. Sequences for the two vouchers of $P$. leucopus were deposited in GenBank: OK263085 and OK263086, respectively.

Range expansion of P. leucopus at the species' northeastern range limit has been reported in the northern Great Lakes (Myers et al. 2009; Moscarella 2011), in southern Quebec (Garcia-Elfring et al. 2017), and in adjacent Maine (Bennett 2020). Such expansion has been attributed mainly to anthropogenic activity, including habitat modification and climate change (Roy-Dufresne et al. 2013; Leo and Millien 2017).

The Blacks Harbour and Lake Utopia specimens are the first evidence that P. leucopus is present on mainland New Brunswick. Lake Utopia is $\sim 14.5 \mathrm{~km}$ north of Blacks Harbour, suggesting that the species is established, at minimum, in the southwestern region of New Brunswick. Mainland New Brunswick records are about $90 \mathrm{~km}$ northeast of coastal Maine reports from Mount Desert Island (Bennett 2020) and about $56 \mathrm{~km}$ northeast of Great Wass Island (Rich 1993). Mount Desert Island is just $300 \mathrm{~m}$ offshore and connected to the mainland by a causeway; Great Wass Island, although about $5 \mathrm{~km}$ offshore, is likewise connected to the mainland by a series of causeways that link adjacent islands. New Brunswick records are about $485 \mathrm{~km}$ east of the nearest confirmed Quebec records (Fiset et al. 2015) and about $350 \mathrm{~km}$ west by land to the nearest Nova Scotia occurrences for P. leucopus (Naughton 2012).

Huynh et al. (2021) reported P. leucopus on Grand Manan Island, but it is unclear how or when the species colonized and established itself there, i.e., historical natural dispersal and (or) recent human transport. Blacks Harbour is the northern terminus for ferries that serve as a daily connection between Grand Manan Island and mainland New Brunswick, ferrying passengers, vehicles, and goods year-round. It is feasible that the ferries are an accessible vector for point of dispersal for Peromyscus. However, it is possible that $P$. leucopus has been present on both Grand Manan and the adjacent mainland for some time but has been previously undetected. This could be because the species occurs at very low densities in the region and has not been collected in the past (Rich 1993) or, more likely, because it has been assumed that all specimens encountered are P. maniculatus and appropriate methods to identify $P$. leucopus have not been used (see Rich et al. 1996). It is also possible that P. leucopus has been present on Grand Manan, as in Nova Scotia, as a relict population and has only recently recolonized southwestern mainland New Brunswick as part of an apparently recent and now well-documented northward range expansion (Fiset et al. 2015).

Garcia-Elfring et al. (2017) noted gene flow between $P$. leucopus and $P$. maniculatus via secondary 


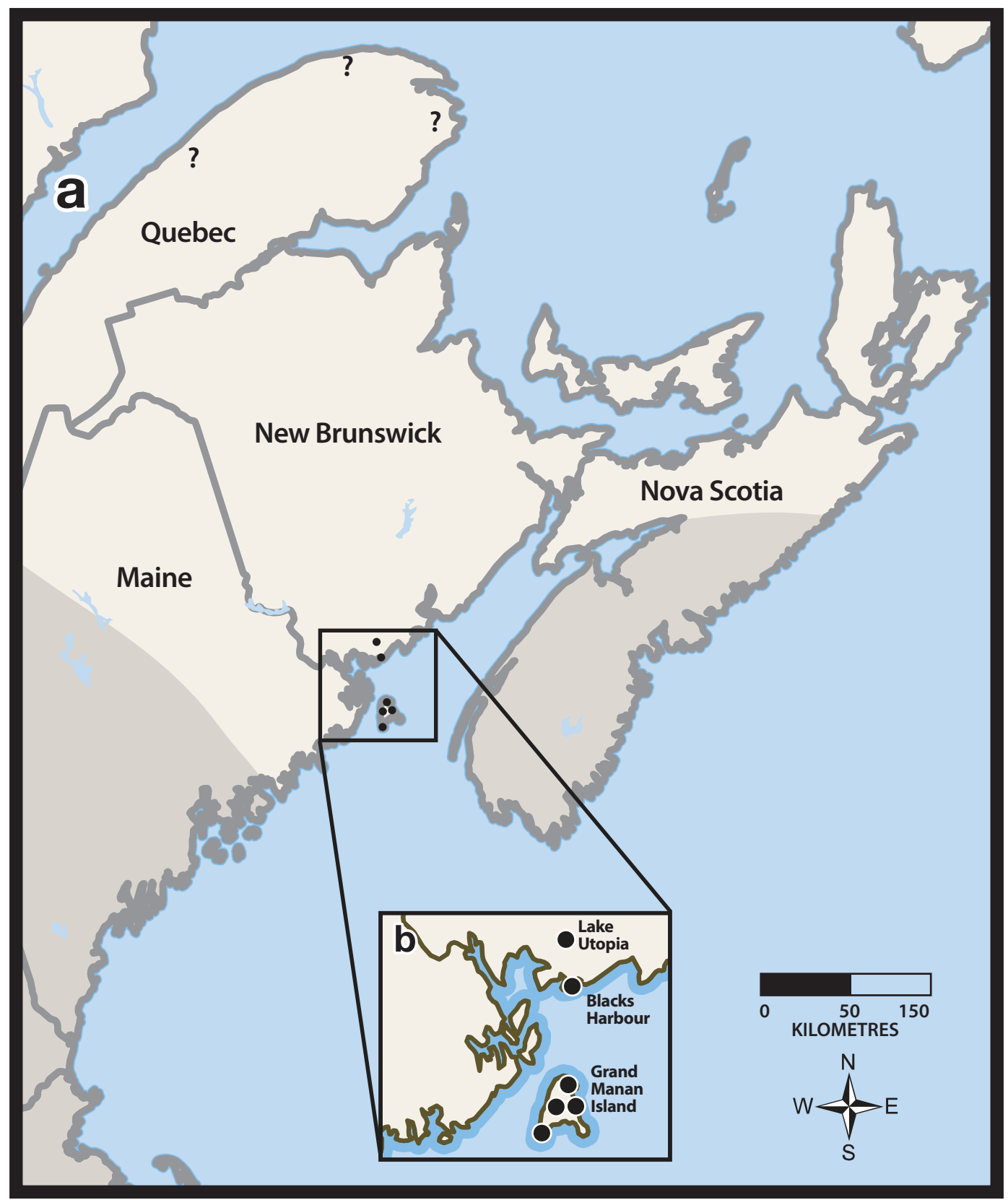

FigURE 1. a. Range of White-footed Deer Mouse (Peromyscus leucopus) in Quebec (?) and Nova Scotia and Maine (shaded area). b. Closed circles mark recent localities for P. leucopus in New Brunswick: Grand Manan Island (Huynh et al. 2021), Blacks Harbour, and Lake Utopia. Unconfirmed Gaspe localities are from Desrosiers et al. (2002).

contact in some populations in southern Quebec, resulting in apparent hybridization and introgression at extremely low frequencies $(n=5$ in a sample of 238). Likewise, working in the same region, Leo and Millien (2017) report low frequencies of apparent hybridization ( $n=5-8$ out of 153 , depending on method of analysis) among $P$. leucopus and $P$. maniculatus. Vrla (2019) used genetic (including sequencing of the cytochrome $b$ gene) and morphometric methods to separate P. leucopus and P. maniculatus in 
western Oklahoma, identifying a series of Peromyscus that are putative hybrids.

Although our use of a single mitochondrial gene to identify $P$. leucopus does not eliminate the possibility that the New Brunswick specimens are of hybrid origin, we believe the probability is low. Previous studies suggest that both pre- and post-zygotic mechanisms ensure that these species are normally well isolated reproductively (e.g., see Leo and Millien 2017 and references therein). Leo and Millen (2017) concluded that the low rate of apparent hybridization appeared to justify their use of the mtDNA COIII gene to separate $P$. leucopus and P. maniculatus, but they noted that recorded natural hybridization between these two congeners may warrant more comprehensive identification methods. Evidence is accumulating that where $P$. leucopus is undergoing range expansion (perhaps associated with climate change), pre-zygotic barriers with $P$. maniculatus may be altered, and hybridization at low rates may occur (Garcia-Elfring et al. 2017; Vrla 2019). Although our results support the presence of P. leucopus in New Brunswick, more detailed analyses will be required to determine the true nature of any genetic interaction between these species in the province.

Regardless of when P. leucopus became established in New Brunswick, the occurrence of the species in the province may have relevance to wildlife management and human health. Although both $P$. leucopus and $P$. maniculatus are considered competent host reservoirs for Borrelia burgdorferi, the spirochete bacterium that causes Lyme disease, there is evidence that $P$. leucopus may be the more competent of the two (Donahue et al. 1987; Garman et al. 1994; Fiset et al. 2015). Peromyscus leucopus also appears to be the preferred host species among rodents for ticks (Ixodes scapularis) that transmit B. burgdorferi (Schmidt et al. 1999). Thus, the apparent geographic expansion of $P$. leucopus, alongside the concurrent range expansion of Lyme disease in Canada (Ogden et al. 2008), may have an impact on the health of human communities in New Brunswick, as has been suggested for southern Quebec (Fiset et al. 2015).

\section{Acknowledgements}

We thank Jagger Watters-Gray and Elise Stevens for their assistance in the Genomics Laboratory at the Canadian Rivers Institute. H.M.H. extends his gratitude to Fenning McAlpine for his kindness during his collecting forays in New Brunswick, Karen Vanderwolf for her assistance in the field, Alfred Gardner for insightful discussions, and Thomas Jung for helpful comments that improved the manuscript. This research was supported by grants from the New Brunswick Wildlife Trust Fund, the Natural Sciences and Engineering Research Council, Canada Research Chairs, the New Brunswick Foundation for Innovation, the Canadian Foundation for Innovation, the New Brunswick Museum, and the University of New Brunswick.

\section{Literature Cited}

Bennett, M.R. 2020. Characterizing the range shifts of two Peromyscus species in Maine. Honors thesis, Honors College, University of Maine, Orono, Maine, USA. Accessed 8 June 2021. https://digitalcommons.library. umaine.edu/honors/580.

Desrosiers, N., R. Morin, and J. Jutras. 2002. Atlas des micromammifères du Québec. Société de la faune et des parcs du Québec, Fondation de la faune du Québec, Québec City, Québec, Canada.

Donahue, J.G., J. Piesman, and A. Spielman. 1987. Reservoir competence of white-footed mice for Lyme disease spirochetes. American Journal of Tropical Medicine and Hygiene 1: 92-96. http://doi.org/10.4269/ajtmh. 1987.36.92

Fiset, J., N. Tessier, V. Millien, and F.-J. Lapointe. 2015. Phylogeographic structure of the white-footed mouse and the deer mouse, two Lyme disease reservoir hosts in Quebec. PLoS ONE 10(12): e0144112. https://doi.org/ 10.1371/journal.pone.0144112

Forbes, G.J., D.F. McAlpine, and F.W. Scott. 2010. Mammals of the Atlantic Maritime Ecozone. Pages 693-718 in Assessment of Species Diversity in the Atlantic Maritime Ecozone. Edited by D.F. McAlpine and I.M. Smith. NRC Research Press, National Research Council Canada, Ottawa, Ontario, Canada.

Garcia-Elfring, A., R.D.H. Barrett, M. Combs, T.J. Davies, J. Munshi-South, and V. Millien. 2017. Admixture on the northern front: population genomics of range expansion in the white-footed mouse (Peromyscus leucopus) and secondary contact with the deer mouse (Peromyscus maniculatus). Heredity 119: 447-458. https:// doi.org/10.1038/hdy.2017.57

Garman, S.L., A.F. O'Connell, Jr., and J.H. Connery. 1994. Habitat use and distribution of the mice Peromyscus leucopus and P. maniculatus on Mount Desert Island, Maine. Canadian Field-Naturalist 108: 67-71. Accessed 11 June 2021. https://www.biodiversitylibrary. org/page/34263673.

Hall, E.R. 1981. The Mammals of North America, Volume II. John Wiley \& Sons, New York, New York, USA.

Huynh, H.M., J. Norman, K.J. Vanderwolf, R.D. Bradley, R.J. Baker, and D.F. McAlpine. 2021. Detection of white-footed deer mouse (Peromyscus leucopus) on Grand Manan Island, New Brunswick, Canada: taxonomic, biogeographic, and human-health implications. Occasional Papers, Museum of Texas Tech University 379: 1-9.

Kaufman, D.W., S.K. Peterson, R. Fristik, and G.A. Kaufman. 1983. Effect of microhabitat features on habitat use by Peromyscus leucopus. American Midland Naturalist 110: 177-185. https://doi.org/10.2307/2425223

Kumar, S., G. Stecher, M. Li, C. Knyaz, and K. Tamura. 2018. MEGA X: molecular evolutionary genetics analy- 
sis across computing platforms. Molecular Biology and Evolution 35: 1547-1549. http://doi.org/10.1093/molbev /msy096

Leo, S.S.T., and V. Millien. 2017. Microsatellite markers reveal low frequency of natural hybridization between the white-footed mouse (Peromyscus leucopus) and deer mouse (Peromyscus maniculatus) in southern Quebec, Canada. Genome 60: 454-463. http://doi.org/10.1139/ gen-2016-0163

Moscarella, R.A. 2011. Dissecting the geographical expansion of Peromyscus leucopus in the northern Great Lakes: insights from genetics, morphometrics and ecology. Ph.D dissertation, Michigan State University, East Lansing, Michigan, USA. https://doi.org/doi:10.25335/ M54192

Myers, P., B.L. Lundrigan, S.M.G. Hoffman, A.P. Haraminac, and S.H. Seto. 2009. Climate-induced changes in the small mammal communities of the Northern Great Lakes Region. Global Change Biology 15: 1434-1454. https://doi.org/10.1111/j.1365-2486.2009.01846.x

Naughton, D. 2012. The Natural History of Canadian Mammals. Canadian Museum of Nature and University of Toronto Press, Toronto, Ontario, Canada.

Ogden, N.H., L. St-Onge, I.K. Barker, S. Brazeau, M. Bigras-Poulin, D.F. Charron, C.M. Francis, A. Heagy, L.R. Lindsay, A. Maarouf, P. Michel, F. Milord, C.J. O'Callaghan, L. Trudel, and R. Thompson. 2008. Risk maps for range expansion of the Lyme disease vector, Ixodes scapularis, in Canada now and with climate change. International Journal of Health Geographics 7: 24. https://doi.org/10.1186/1476-072X-7-24

Rich, S.M. 1993. Distribution, biogeography and population genetics of Peromyscus leucopus and Peromyscus maniculatus in New England and Maritime Canada. M.Sc. thesis, University of Vermont, Burlington, Vermont, USA.

Rich, S.M., C.M. Kilpatrick, J.L. Shippee, and K.L. Cro- well. 1996. Morphological differentiation and identification of Peromyscus leucopus and P. maniculatus in Northeastern North America. Journal of Mammalogy 77: 985-991.

Roy-Dufresne, E., T. Logan, J.A. Simon, G.L. Chmura, and V. Millien. 2013. Poleward expansion of the white-footed mouse (Peromyscus leucopus) under climate change: implications for the spread of Lyme disease. PLoS ONE 8(11): e80724. https://doi.org/10.1371/ journal.pone.0080724

Schmidt, K.A., R.S. Ostfeld, and E.M. Schauber. 1999. Infestation of Peromyscus leucopus and Tamias striatus by Ixodes scapularis (Acari: Ixodidae) in relation to the abundance of hosts and parasites. Journal of Medical Entomology 36: 749-757. https://doi.org/10.1093/jmed ent $/ 36.6 .749$

Smith, M.F., and J.L. Patton. 1993. The diversification of South American rodents: evidence from mitochondrial sequence data for the akodontine tribe. Biological Journal of the Linnean Society 50: 149-177. https://doi. org/10.1111/j.1095-8312.1993.tb00924.x

Tiemann-Boege, I.C., C.W. Kilpatrick, D.J. Schmidly, and R.D. Bradley. 2000. Molecular phylogenetics of the Peromyscus boylii species group (Rodentia: Muridae) based on mitochondrial cytochrome $b$ sequences. Molecular Phylogenetics and Evolution 16: 366-378. https://doi.org/10.1006/mpev.2000.0806

Vrla, S.C. 2019. Genetic structure and the potential for hybridization in populations of Peromyscus spp. of plateau regions in western Oklahoma. M.Sc. thesis, University of Central Oklahoma, Edmond, Oklahoma, USA. Accessed 8 June 2021. https://shareok.org/bitstream/ handle/11244/325125/VrlaSC2019.pdf.

Received 20 September 2020

Accepted 9 June 2021

Associate Editor: T.S. Jung 